\title{
Management Teachers in the Implementation of Learning Process in The Industrial Revolution 4.0
}

\author{
Tati Mulyani \\ SD Negeri 10 Banyuasin III \\ Email: tatimulyani878@gmail.com \\ Edi Harapan \\ Universitas PGRI Palembang, Indonesia \\ e-mail: ehara205@gmail.com \\ Nila Kesumawati \\ Universitas PGRI Palembang, Indonesia \\ e-mail: nilakesumawati@yahoo.com \\ Article History: Received on 20 November 2021, Revised on 25 January 2022 \\ Published on 2 February 2022
}

\begin{abstract}
This study attempts to teacher management class in the implementation of learning process of SD Negeri 10 Banyuasin III in the industrial revolution 4.0. Qualitative was used of this research. Informants were the principals and 10 teachers of SD Negeri 10 Banyuasin III. Data collection technique using a questionnaire. The results suggest that teacher management class in the implementation of the learning process had been considered good and capable on management implementation of the learning process. The obstacles were lack of skill in new technologies.
\end{abstract}

Keywords: Management Class, Teachers, Learning Process, Industrial Revolution 4.0

\section{A. Introduction}

Education in the industrial revolution 4.0 describe various ways integrated the technology cyber whether physical or non-physical in learning. It will be covered by a challenge for human teachers to implement. Programs development especially in the quality of teachers should be done to get quality in education (Sumardin, 2016).

Class management is the main focus of education often used by teachers, new teacher, then students can learn optimaly. According to Gangsar (2012) class management problem is complex behavior, and teachers use it to create and maintain condition class in such a way that students able to accomplish a purpose in an efecient teaching (Zulaiha et al, 2020).

Based on preliminary data, we found where infrastructure do not support adequate of learning in industrial revolution 4.0. Follow up from the education and counseling delivered and guide for students who difficulties in learning. Our interviews with school principals obtained information that the implementation of the teacher management class are considered good (Lian, 2019).

Teachers obey the regulation according to directed, but because the limitation of facilities study in public primary schools as the SD Negeri 10 Banyuasin III learning like the school aids, in 
library books which is still considered minimal, and funds and must work in full by using what is delivered so that the education can run well as expected (Mukhtar et al, 2020).

The teaching process in SD Negeri 10 Banyuasin III was assisted by 14 teachers consisting of 6 honorary and 8 civil servant. Four from 8 the new civil servant teachers have a certificate while others not. The process of learning by teachers were based on capability owned and teachers use media in school with the theme discussed at the learning. Teachers sometimes use books to add the subject.

The learning management, not all teachers are able to handle class well, because the capability of teachers were vary. The school always tried to manage and improve teachers in class. But the obstacles is the lack of class in managing the capability of teachers, lack of training teachers and seldom on attendance. This used to be the homework of school principals to offer the best for teachers in managing the better class. The rapid technology development, it takes teachers should be good and professional. School principals also added information to implement the curriculum 2013.

\section{B. Methods}

This study is qualitative and done in field directly to obtain data needed. This study specifically designed to describe the social phenomena in the pertaining of management teachers in the learning relevant with the industrial revolution 4.0. Informants in this study were teachers of SD Negeri 10 Banyuasin III. Data collection in this study using interviews, observation and documentation. The data analysis were done through triangulation.

\section{Results and Discussion}

Competence of teachers in the implementation of learning is considered good where teachers are capable of conveying learning. In the management of class, the teachers ara capable to set a seat of students, set the moving class 1 month with a seat shuffle. Teachers are considered capable to set liveliness student learning which were deemed to have smart enough and students able to answer the given question whether orally and written on the blackboard. As a mediator and facilitator teachers help students to lend textbooks and help students to learn. As evaluator, teachers can do the evaluation of those lessons daily, per semester and at the end of learning (Surani, 2019; Utomo, 2019).

Teachers in SD Negeri 10 Banyuasin III always take training, the seminar, workshop, and participate in competency test, where they obtain good results and receive a certificate. This is proven in 2014 which add one teacher having a certificate. While those do not yet get only two teachers.

Obstacles that teachers face in the implementation of learning in the industrial revolution 4.0 is the lack of teaching aids, lack of media as a source of learning (Risdianto et al, 2020). There is still many students do not want to sit in front of and they do not want also to sit in the back, as a mediator, teacher helped students who had a learning disability such as students who still difficulty in reading and writing even though has given guidance wisely.

There are relevant research Fitria (2019) there are 14 items as standard, the facilities and infrastructures, standard classrooms, the library, biological laboratory, physics laboratory, 
Volume 3 (1) 2022

E-ISSN: 2723-6919 P-ISSN: 2746-0827

chemical laboratory, computer laboratory, language laboratory, the teachers' room, school health units, space of student organization, privy, the warehouse, the circulation of the space, and the space of sport. While the facilities and infrastructures conforming to: space, administrative worship center, and the counseling room. School principals have implemented as the school administrative functions to fix school infrastructure that is planning on function, coordination, accountability to optimize infrastructure in improving the process of learning. Based on fitria findings it to adequate infrastructure supporting the implementation of the teacher management class of learning in SD Negeri 10 Banyuasin III.

The industrial revolution 4.0 identified as follow 1) the safety information technology; 2) increase the reliability and stability; 3) increase the production of skill; 4) a reluctance by stakeholders to change; and 5) loss of much work because of automation. The challenges and changes, requires college to keep running various roles such as education and teaching, the development and dissemination for the science. The higher education in industrial era is in line with the hope to have world class universities and can survive and grow according 4.0 demands in the industrial revolution. The result of this research was strengthening the world cyber technology require teachers to able to compete and understand the importance of technology (Sukartono, 2019).

Khotimah et al (2020) explain the quality of teachers contributed to increase the authority schools in Tanjung Raja. The result of this study is simply strengthen the quality of teachers in teaching, determine the success of students, and focus on the good class management which is expected gaining learning process run well (Hasibuan, 2019).

\section{Conclusion}

Based on the results, it concludes that the class management of teachers in the implementation of the learning process had been considered good. The obstacles were lack of skill in new technologies.

\section{E. Acknowledgement}

Thank to principal and teachers of SD Negeri 10 Banyuasin III, Rector Universitas PGRI Palembang and friends of in educational management who have supported us to do this valuable project.

\section{References}

Fitria, H. (2019). Manajemen Sarana Prasarana dalam Meningkatkan Proses Pembelajaran [Infrastructure Management in Improving the Learning Process]. Prosiding Seminar Nasional Pendidikan Program Pascasarjana Universitas PGRI Palembang, 12 January 2019, Page 58-65.

Gangsar, F. U. (2012). Kemampuan Guru Mengelola Kelas 4 dan 5 SD Negeri Pandeyan Umbulharjo Yogyakarta [Teacher Ability to Manage Grades 4 and 5 SD Negeri Pandeyan Umbulharjo Yogyakarta]. Jurnal Manajemen Pendidikan, 3(2), 236-251.

Hasibuan, A. T. (2019). Sekolah Ramah Anak Era Revolusi Industri 4.0 di SD Muhammadiyah Pajangan 2 Berbah Yogyakarta [Child Friendly Schools in the Industrial Revolution Era 

Manajemen Pendidikan, 11(1).

Khotimah, H., Harapan, E., \& Kesumawati, N. (2020). Kualitas Guru Mengajar Sebagai Salah Satu Upaya Meningkatkan Status Akreditasi Sekolah [Quality of Teaching Teachers as an Effort to Improve School Accreditation Status]. JMKSP (Jurnal Manajemen, Kepemimpinan, dan Supervisi Pendidikan), 6(1), 124-132.

Lian, B. (2019). Revolusi Industri 4.0 dan Disrupsi, Tantangan dan Ancaman Bagi Perguruan Tinggi [Industrial Revolution 4.0 and Disruption, Challenges and Threats for Higher Education]. Prosiding Seminar Nasional Pendidikan Program Pascasarjana Universitas PGRI Palembang, 12 January 2019, 40-45.

Mukhtar, M., Hidayat, H., \& Duyardin, D. (2020). Management of the Center for Early Childhood Education Development in Improving the Quality of Early Childhood Education in Jambi Province. Journal of Social Work and Science Education, 1(2), 115126. https://doi.org/10.52690/jswse.v1i2.36

Risdianto, E., Fitria, J., Johan, H., \& Macariola, J. S. (2020). Teacher's Perception of Thermodynamic Law Module Developed in Training through Student's Critical Thinking Skills. Journal of Social Work and Science Education, 1(1), 78-86. https://doi.org/10.52690/jswse.v1i1.19

Sukartono. (2019). Pendidikan dalam Era Revolusi Industri 4.0. Indonesia "7 Provinsi Raih Nilai Terbaik Uji Kompetensi Guru 2015" [Education in the Industrial Revolution Era 4.0. Indonesia "7 Provinces Achieved the Best Scores in the 2015 Teacher Competency Test"]. Jurnal Manajemen Pendidikan, XI(2), 312-326.

Sumardin. (2016). Pengembangan Profesionalisme Guru Berbasis MGMP Model dan Implementasinya [Teacher Professionalism Development Based on MGMP Model and Its Implementation]. Yogyakarta: Budi Utama.

Surani, D. (2019). Studi Literatur: Peran Teknolog Pendidikan dalam Pendidikan 4.0 [Literature Study: The Role of Educational Technologists in Education 4.0]. Jurnal Manajemen Pendidikan, 2(1), 456-469.

Utomo, S. S. (2019). Guru di Era Revolusi Industri 4.0 [Teachers in the Industrial Revolution 4.0]. Jurnal Manajemen Pendidikan, XIV(3), 322-335.

Zulaiha, D., Lian, B., \& Mulyadi, M. (2020). The Effect of Principal's Competence and Community Participation on the Quality of Educational Services. Journal of Social Work and Science Education, 1(1), 45-57. https://doi.org/10.52690/jswse.v1i1.9 